\title{
Relationship between Category of Weight and Threshold of Maximum Oxidation of Lipids in Congolese Judoists
}

\author{
Jean Georges André Moulongo ${ }^{1,2 *}$, Alphonse Massamba1,2, Jean Itoua Okemba², \\ Massala Kitanga Fêtra Néla², Packa Bernard Tchissambou ${ }^{1}$
}

\footnotetext{
${ }^{1}$ Laboratory of Physiology of the Effort and Biomechanics, Higher Institute of Physical and Sporting Education, Marien Ngouabi University, Brazzaville, Congo

${ }^{2}$ Martial Arts and Combat Sports Research Unit, Fundamental and Applied Human Movement Sciences Laboratory, Higher Institute of Physical Education and Sports, Marien Ngouabi University, Brazzaville, Congo

Email: *jgamoulongo@gmail.com
}

How to cite this paper: Moulongo, J.G.A., Massamba, A., Itoua Okemba, J., Néla, M.K.F. and Tchissambou, P.B. (2017) Relationship between Category of Weight and Threshold of Maximum Oxidation of Lipids in Congolese Judoists. Journal of Biosciences and Medicines, 5, 74-83.

https://doi.org/10.4236/jbm.2017.57007

Received: April 25, 2017

Accepted: July 25, 2017

Published: July 28, 2017

Copyright () 2017 by authors and Scientific Research Publishing Inc. This work is licensed under the Creative Commons Attribution International License (CC BY 4.0).

http://creativecommons.org/licenses/by/4.0/

\begin{abstract}
Background: One of the goals for training in judo is to mimic real situations. In subsaharian countries; there is a lack of knowledge considering relation between category of weight and threshold maximum oxidation of lipids. $\mathrm{Ob}$ jectives: The main objectives of this study were to analyze the effect of category of weight on lipox $x_{\max }$ and to identify the zones of target intensities corresponding to lipox ${ }_{\max }$. Materials and Methods: Twenty four male welltraining judoists, divided in two groups according to weight, were evaluated during calorimetry effort' test. For this situation, cardiorespiratory parameters ( $\mathrm{HR}, \mathrm{VO}_{2}, \mathrm{VO}_{2 \max }$ ), blood parameter (lactatemia), anthropometric variables and zones of target corresponding to lipox were evaluated. For statistical analysis, Shapiro-Wilks test was used to compare all the data and differences were confirmed by one-way variance. Results: No significant differences were observed among two groups for target intensities to lipox. The judoists of group 1 were aged to $24.1 \pm 5.9$ years with $1.78 \pm 0.07 \mathrm{~m}$ versus $20.4 \pm 1.6$ years with $1.86 \pm 0.04 \mathrm{~m}$. Primary results indicated higher intensities for lipox $_{\max }$. Also, values of power (\% LDC) and $\mathrm{VO}_{2}$ and were significantly higher in the judoists for group 2, with respectively: $45.3 \pm 10.2$ and $46.4 \pm 8.6$ $\mathrm{ml} / \mathrm{min}$ versus $38.2 \pm 7.2$ and $31.3 \pm 7.6 \mathrm{ml} / \mathrm{min}$. Conclusion: High weight in judoists induces high intensities of lipox $_{\max }$ and change oxidation of lipids markers following training.
\end{abstract}

\section{Keywords}

Judo, Oxidation of Lipids, Lipox ${ }_{\max }$, Weight Category 


\section{Introduction}

The most important role played by glucides and lipids energy supply for cell functions bias substrates used by aerobic metabolism to provide energy to the muscles at the time of average and long duration exercises [1] [2]. To oxidize maximum of lipids, the literature reveals that intensity's effort ranging between $31 \%$ and $63 \%$ of oxygen maximum uptake $\left(\mathrm{VO}_{2} \mathrm{max}\right)$ must be generally carried out [3] [4] [5]. However, the width of this zone of intensity makes that it is difficult to prescribe the intensity corresponding to the point of maximum oxidation of the lipids (Lipox ${ }_{\max }$. This observation can be explained by heterogeneity of studied populations, particularly in terms of level of performance. Indeed, the aerobic drive generally produces an increase in the maximum flow of oxidation of the lipids (DMOL) and a shift towards the line of Lipox $\max _{\text {ax }}$ [6]. Consequently, sportsmen must involve themselves with intensities of exercise higher than sedentary subjects, to oxidize a maximum of lipids [7]. However, according to our knowledge, no study studied Lipox $\max _{\max }$ of judoists. This specific combat sport has a combination of rules that confers singular characteristics to judo (e.g., grappling-based techniques or striking-based techniques; scoring system; time duration of round; distribution of gender; organization in weight divisions) [8]. Despite these characteristics, studies have shown that judois regarded as a combat sport on high level intensity and intermittent sport [9] [10]. However, judo is a sport with dominant anaerobic-aerobic way; it is characterized by seven categories of weight: $<60 \mathrm{~kg}$; $<66 \mathrm{~kg}$; $<73 \mathrm{~kg} ;<81 \mathrm{~kg} ;<90 \mathrm{~kg}$; $<100 \mathrm{~kg}$; $>100 \mathrm{~kg}$ according to recommendations of International Federation of Judo (IFJ). Another important characteristic of judo is the long duration of a competitive event. While a professional fight may last up to five 5-minute, judo may perform up to seven matches in the same day. Consequently, if Lipox $x_{\max }$ is similar in the judoists of less than $66 \mathrm{~kg}$ and those of $90 \mathrm{~kg}$, it will be then possible to establish a narrow zone of intensities target common making it possible to prescribe Lipox $_{\max }$ precisely.

This study aimed thus to examine the influence of the category of weight on Lipox $_{\max }$ of the judoists, like identifying the zones of target intensities corresponding to Lipox $_{\max }$. Insofar as the lipids (triglycerides) stored in the organization constitute one of two principal sources of energy during muscular exercise, a better comprehension of the metabolism of fat during the training in the judoists of various categories proves to be necessary.

\section{Materials and Methods}

\subsection{Subjects}

For this study, 24 judoists, aged from 18 to 35 years, all involved on the high level but of different categories of weight, were recruited (Table 1 and Table 2). These judoists were separate in two groups according to their category of weight (Table 1 and Table 2). Group 1 consisted of 17 judoists of less than $66 \mathrm{~kg}$, group 2 formed of 7 judoists of more than $90 \mathrm{~kg}$. 
Table 1. Anthropometric characteristics, physiological and related to the training of the 17 judoists of group 1 and the 24 judoists (group 1 and 2).

\begin{tabular}{lccccc}
\hline & \multicolumn{2}{c}{ Group 1} & Together of the 24 judoists & \\
\cline { 2 - 5 } & Mean \pm SD & CI 95\% & Mean \pm SD & CI 95\% & \\
\hline Age (years) & $24.1 \pm 5.9$ & 2.7 & $22.2 \pm 5.3$ & 2.1 & 0.03 \\
Height (cm) & $178.0 \pm 7.0$ & 3.0 & $182.0 \pm 6.0$ & 2.0 & 0.47 \\
Body mass (kg) & $64.2 \pm 1.1$ & 2.8 & $83.8 \pm 0.6$ & 2.3 & 0.001 \\
Lubricate (\%) & $12.4 \pm 1.9$ & 0.9 & $15.3 \pm 1.9$ & 0.7 & 0.24 \\
Experiment (years) & $9.4 \pm 5.3$ & 2.4 & $9.9 \pm 4.6$ & 1.8 & 0.49 \\
Weekly volume of drive (h) & $9.9 \pm 2.7$ & 1.3 & $11.4 \pm 3.6$ & 1.4 & $<0.01$ \\
LDC (w) & $343 \pm 25$ & 11 & $345 \pm 24$ & 10 & 0.92 \\
VO ${ }_{2}$ max (ml/min) & $4345 \pm 430$ & 199 & $5903.7 \pm 727.0$ & 156 & 0.75 \\
VO ${ }_{2}$ max (ml/kg/min) & $69.2 \pm 2.1$ & 3.1 & $63.8 \pm 2.7$ & 2.5 & 0.39 \\
RQmax & $1.11 \pm 0.05$ & 0.02 & $1.24 \pm 0.07$ & 0.03 & 0.12 \\
FCmax (bpm) & $192 \pm 8$ & 4 & $194 \pm 8$ & 3 & 0.26 \\
[La- (mmol/l) & $12.8 \pm 2.6$ & 1.2 & $13.1 \pm 2.7$ & 1.1 & 0.58 \\
$\mathrm{RPEmax}^{-}$ & $19.1 \pm 1.1$ & 0.5 & $19.1 \pm 1.1$ & 0.4 & 0.48 \\
\hline
\end{tabular}

Abbreviations: $p$, level of significance; $\mathrm{LDC}$, aerobic maximum power; $\mathrm{VO}_{2}$ max, maximum consumption of oxygen; QRmax, respiratory quotient maximum; FC max, maximum heart rate; $\left[\mathrm{La}^{-}\right]$, maximum lactatemy; RPEmax, maximum perception of the effort.

Table 2. Anthropometric characteristics, physiological and related to the training of the 7 judoists of group 2 and the 24 judoists (group 1 and 2).

\begin{tabular}{|c|c|c|c|c|c|}
\hline & \multicolumn{2}{|l|}{ Group 2} & \multicolumn{2}{|c|}{ Together of the 24 judoists } & \multirow{2}{*}{$\mathbf{P}$} \\
\hline & Mean \pm SD & CI 95\% & Mean \pm SD & CI 95\% & \\
\hline Age (years) & $20.4 \pm 1.6$ & 1.4 & $22.2 \pm 5.3$ & 2.1 & 0.03 \\
\hline Height $(\mathrm{cm})$ & $186.0 \pm 4.2$ & 3.1 & $178.0 \pm 6.0$ & 2.0 & 0.36 \\
\hline Body mass (kg) & $103.4 \pm 0.8$ & 1.4 & $83.8 \pm 0.6$ & 2.3 & 0.001 \\
\hline Lubricate (\%) & $18.2 \pm 0.3$ & 1.0 & $15.3 \pm 1.9$ & 0.7 & 0.23 \\
\hline Experiment (years) & $11.0 \pm 2.2$ & 1.6 & $9.9 \pm 4.6$ & 1.8 & 0.49 \\
\hline Weekly volume of drive (h) & $15.0 \pm 1.9$ & 2.2 & $11.4 \pm 3.6$ & 1.4 & $<0.001$ \\
\hline $\operatorname{LDC}(w)$ & $350 \pm 25$ & 19 & $345 \pm 24$ & 10 & 0.92 \\
\hline $\mathrm{VO}_{2} \max (\mathrm{ml} / \mathrm{min})$ & $6462.5 \pm 1024.0$ & 417 & $5903.7 \pm 727.0$ & 156 & 0.75 \\
\hline $\mathrm{VO}_{2} \max (\mathrm{ml} / \mathrm{kg} / \mathrm{min})$ & $62.5 \pm 5.0$ & 3.7 & $63.8 \pm 3.4$ & 2.5 & 0.39 \\
\hline RQmax & $1.38 \pm 0.08$ & 0.06 & $1.24 \pm 0.07$ & 0.03 & 0.32 \\
\hline FCmax (bpm) & $199 \pm 7$ & 5 & $194 \pm 8$ & 3 & 0.26 \\
\hline$\left[\mathrm{La}^{-}\right](\mathrm{mmol} / \mathrm{l})$ & $14.0 \pm 3.3$ & 2.4 & $13.1 \pm 2.7$ & 1.1 & 0.58 \\
\hline RPEmax & $19.0 \pm 1.2$ & 0.9 & $19.1 \pm 1.1$ & 0.4 & 0.48 \\
\hline
\end{tabular}

Abbreviations: $\mathrm{p}$, level of significance; $\mathrm{LDC}$, aerobic maximum power; $\mathrm{VO}_{2}$ max, maximum consumption of oxygen; QRmax, respiratory quotient maximum; FC max, maximum heart rate; $\left[\mathrm{La}^{-}\right]$, maximum lactatemy; RPEmax, maximum perception of the effort. 


\subsection{Material}

\subsubsection{Cycloergometer}

The test of calorimetry of effort was led on a cycloergometer to electromagnetic brake (Ergoline S 300, Medisoft ${ }^{\circledR}$ Dinant, Belgium). This cycloergometer made it possible to the judoists to maintain a power selected by adjustments of resistance according to the cycling frequency.

\subsubsection{Cardiorespiratory Parameters}

The effort was evaluated by calorimetrytest with an electrocardiogram with 12 ways (Medcard, Medisoft ${ }^{\varpi}$ Sorinnes, Belgium) which was connected to the analyzer of gaseous exchange. The oxygen uptake $\left(\mathrm{VO}_{2} \max \right)$, the production of carbon dioxide $\left(\mathrm{VCO}_{2}\right)$ and the respiratory quotient (RQ) were measured in cycle with cycle with a measuring equipment in open circuit (Ergocard, Medisoft $^{\oplus}$ Dinant, Belgium). Data-processing software used Exp'air (Medisoft ${ }^{\oplus}$ Dinant, Belgium). This apparatus was gauged according to recommendations' of the manufacturer. A syringe of 31 (Calibration pump, Medisoft ${ }^{\oplus}$ Dinant, Belgium) was used for the calibration of volumes, while the calibration of gases was carried out thanks to the ambient air (i.e., environmental temperature and atmospheric pressure) and to a gas standard, whose concentrations were known ( $16 \%$ of oxygen and $4 \%$ of $\mathrm{CO}_{2}$ ).

\subsubsection{Blood Parameters}

The blood concentration in lactates $\left[\mathrm{La}^{-}\right]$was determined by a system of analysis ABL800Flox (Radiometer medical ${ }^{\oplus}$ Copenhagen, Denmark).

\subsubsection{Rating of Perceived Exertion [RPE]}

The RPE was measured using the French translation of scale RPE of Borg (1970) [11].

\subsubsection{Height, Body Mass and Fat}

The size, the body mass and the thickness of the cutaneous folds were measured with a mural measuring apparatus (model 220, Seca ${ }^{\bowtie}$ Hamburg, Germany), a gauged balance (TBF 543, Tanita ${ }^{\oplus}$ Tokyo, Japan) and anadipometer (HSK-B 1 Body Care ${ }^{\varpi}$ Warwickshire, England), respectively. Methods of Durnin and Wormersley (1974) [12] were used for evaluate thickness of the cutaneous folds.

\subsection{Method}

Before the realization of the calorimetry test, the judoists signed a note of information and a form of assent their retailer the goal and the procedure of the investigation. This study was approved by the National Council of Ethics of Biomedical Research of Congo.

\section{Test of Calorimetry of Effort}

The test was preceded by one period by rest by at least three minutes in order to measure the cardiorespiratory parameters in a basal state. Then, an eight minutes heating with $100 \mathrm{w}$, followed by one period of five minutes passive recov- 
ery on the cycloergometer was carried out. Following the latter, the judoists began the calorimetrytest.

During this test, the initial power was fixed at $150 \mathrm{w}$ (during four minutes) and the increment was of $50 \mathrm{w}$ every four minutes until $300 \mathrm{w}$. Of the four minute old stages were selected because it was already reported that one three minutes duration is valid to determine Lipox ${ }_{\max }$ of the high level judoists [13]. Moreover, obtaining a stable state of the gaseous exchange $\left(\mathrm{VO}_{2}\right.$ and $\left.\mathrm{VCO}_{2}\right)$ during the last minute of each stage was controlled. Once the load of $300 \mathrm{w}$ reached, the increment of power was of $25 \mathrm{w}$ every two minutes, and this until exhaustion (incapacity of the judoist to maintain a cycling frequency above 70 revolutions per minute (rpm) during more than five seconds. The judoists were to develop the greatest possible power. The latter corresponded to the aerobic maximum power (LDC). To reach the LDC, verbal encouragements were given to judoists at the time of the intensities higher than $300 \mathrm{w}$.

During the test, the heart rate (FC), the $\mathrm{VO}_{2}$, the $\mathrm{VCO}_{2}$ and the RQ were measured continuously, then realised during the 30 last seconds of each stage. Then, the share of oxidation of the lipids was given starting from the formula (which was applied to the first four stages):

[Lipids] $(\mathrm{mg} / \mathrm{min})=-1.7012 \mathrm{VCO}_{2}(\mathrm{ml} / \mathrm{min})+1.6946 \mathrm{VO}_{2}(\mathrm{ml} / \mathrm{min})$.

The climax of the relation between the power and oxidation of lipids (bellshaped curve) corresponded to Lipox $_{\max }$.

In complement of these measurements, the general RPE were raised at the end of each stage. A sample of blood was taken with the stop of the test. Exhaustiveness was checked by the attack from at least three of the five following criteria:

- A plate in $\mathrm{VO}_{2}$ max;

- An increase in the $\mathrm{VO}_{2}$ lower than $150 \mathrm{ml} / \mathrm{min}$ in spite of a rise in the power;

- A QR higher than 1.1;

- A FC max measured to $90 \%$ of the FC max predicted;

- One $\left[\mathrm{La}^{-}\right]$higher than $8 \mathrm{mmol} / \mathrm{l}$ with the stop of the exercise;

- A value of RPE from at least 18 at the time of the last entirely supplemented stage.

\subsection{Experimental Methods}

At a preliminary session, size, body mass and percentage of fat were given [9]. During this meeting, the judoists were familiarized on scale RPE. Moreover, one recommendation of this one and of its recommendations was provided to the judoists, so that they use them at the time of their drives. During this meeting, it was specified with the judoists that they were to avoid the physical activities exhausting during the 48 hours preceding the test.

The recommendations of scale RPE were read and explained to the judoists, right before the test to help the judoists to bind their stimuli to the values of RPE. The period pretest was also used to regulate the heights of saddle and guide.

During the test, the judoists were to maintain a cycling frequency continuously 
ranging between 70 and $100 \mathrm{rpm}$. The air of the room was air-conditioned and the temperature maintained between $20^{\circ} \mathrm{C}$ and $24^{\circ} \mathrm{C}$. The test was always carried out under medical control (cardiologist and lung specialist).

\subsection{Statistical Analysis}

The results are expressed in the average form standard deviation (SD) and of confidence interval (CI) at 95\% (IC95\%). The normality of the distribution of the data was checked by the test of Shapiro-Wilks, while the homogeneity of the variance was confirmed by the Levene'stest. An analysis of variance (ANOVA) to a factor (G1 versus G2) was used to compare all the data. The threshold of significativity was fixed at 0.05 for all the analyses. The statistical data processing was carried out with software Statview 5 .

\section{Results}

The anthropometric and physiological characteristics of the judoists are presented in Table 1 and Table 2 . The judoists of group 2 were significantly younger $(20.4 \pm 1.6$ years versus $24.1 \pm 5.9$ years; $\mathrm{p}<0.03)$ and significantly spent $(\mathrm{p}<$ $0.01)$ more time being involved in training $(15.0 \pm 1.9$ days against $9.9 \pm 2.7$ days) weekly than judoists of group 1 . The RQ recorded before the stop of the test of the judoists of G2 was significantly higher than that of the judoists of G1 $(1.38 \pm 0.08$ versus $1.11 \pm 0.05 ; \mathrm{p}<0.12)$.

Table 3 and Table 4 bring back the target intensities corresponding to Lipox$\max _{\max }$ in the two groups of judoists. These intensities were not significantly different, except for the zones of FC and percentage of FCmax. For these last, the judoists of G2 had zones significantly higher in comparison with the judoists of G1 $(112 \pm 11 \mathrm{bpm}$ versus $129 \pm 13 \mathrm{bpm}$ and $58.6 \% \pm 6.1 \%$ versus $65.0 \% \pm 6.5 \% \mathrm{FC}$ $\max \mathrm{p}<0.05)$.

Table 3. Zones of target intensities corresponding to Lipox $x_{\max }$ of the 17 judoists of group 1 .

\begin{tabular}{|c|c|c|c|c|c|c|c|c|c|}
\hline & \multicolumn{4}{|c|}{ Group 1} & \multicolumn{4}{|c|}{ Groups 1 et 2} & \multirow{2}{*}{$\mathbf{P}$} \\
\hline & Mean \pm SD & CI 95\% & $\mathrm{Xmin}$ & $\mathrm{Xmax}$ & Mean \pm SD & CI 95\% & $\mathrm{Xmin}$ & $\mathrm{Xmax}$ & \\
\hline Flow $(\mathrm{mg} / \mathrm{min} / \mathrm{kg})$ & $5.6 \pm 2.5$ & 1.1 & 4.5 & 6.8 & $5.9 \pm 2.7$ & 1.1 & 4.8 & 7.0 & 0.40 \\
\hline Power (w) & $132 \pm 31$ & 14 & 117 & 146 & $139 \pm 33$ & 13 & 126 & 152 & 0.50 \\
\hline Power (\% LDC) & $38.2 \pm 7.2$ & 3.3 & 34.9 & 41.6 & $40.3 \pm 8.6$ & 3.4 & 37 & 44 & 0.70 \\
\hline $\mathrm{VO}_{2}(\mathrm{ml} / \mathrm{min})$ & $27.6 \pm 5.5$ & 2.5 & 25.1 & 30.1 & $28.7 \pm 6.2$ & 2.5 & 26 & 31 & 0.30 \\
\hline $\mathrm{VO}_{2}\left(\% \mathrm{VO}_{2} \max \right)$ & $42.4 \pm 7.1$ & 3.3 & 39.1 & 45.7 & $43.6 \pm 7.6$ & 3.0 & 41 & 47 & 0.25 \\
\hline $\mathrm{VO}_{2}\left(\% \mathrm{VO}_{2}\right.$ réserve $)$ & $37.7 \pm 8.2$ & 3.8 & 33.9 & 41.4 & $38.9 \pm 8.6$ & 3.4 & 35 & 42 & 0.29 \\
\hline FC (bpm) & $112 \pm 11$ & 5 & 107 & 117 & $119 \pm 34$ & 14 & 105 & 133 & $<0.01$ \\
\hline FC (\%FC max) & $58.6 \pm 6.1$ & 2.8 & 55.8 & 61.4 & $60.6 \pm 6.8$ & 2.7 & 5.8 & 63 & 0.03 \\
\hline FC (\%FC holds) & $47.5 \pm 18.6$ & 8.6 & 39.0 & 56.1 & $51.4 \pm 19.1$ & 7.6 & 44 & 59 & 0.17 \\
\hline RPE & $9.9 \pm 3.3$ & 2.5 & 7.5 & 12.4 & $9.2 \pm 2.7$ & 1.1 & 8 & 10 & 0.38 \\
\hline
\end{tabular}

Abbreviations: $\mathrm{p}$, level of significance; $\mathrm{LDC}$, aerobic maximum power; $\mathrm{Lipox}_{\max }$ threshold of maximum oxidation of the lipids; $\mathrm{VO}_{2}$ oxygen uptake; $\mathrm{VO}_{2}$ max, consumption maximum of oxygen; $\mathrm{VO}_{2}$ oxygen uptake $\mathrm{VO}_{2}$ réserve consumption holds of oxygen; FC max, maximum heart rate; $\mathrm{RPE}$, perception of the effort. 
Table 4. Zones of target intensities corresponding to Lipox ${ }_{\max }$ of the 7 judoists of group 2.

\begin{tabular}{|c|c|c|c|c|c|c|c|c|c|}
\hline & \multicolumn{4}{|c|}{ Group 1} & \multicolumn{4}{|c|}{ Groups 1 et 2} & \multirow{2}{*}{$\mathbf{P}$} \\
\hline & Mean \pm SD & CI 95\% & $\mathrm{Xmin}$ & $\mathrm{Xmax}$ & Mean \pm SD & CI 95\% & $\mathrm{Xmin}$ & $\mathrm{Xmax}$ & \\
\hline Flow $(\mathrm{mg} / \mathrm{min} / \mathrm{kg})$ & $6.7 \pm 3.4$ & 2.5 & 4.2 & 9.2 & $5.9 \pm 2.7$ & 1.1 & 4.8 & 7.0 & 0.40 \\
\hline Power (w) & $158 \pm 34$ & 25 & 132 & 183 & $139 \pm 33$ & 13 & 126 & 152 & 0.50 \\
\hline Power (\% LDC) & $45.3 \pm 10.2$ & 7.6 & 37.7 & 52.8 & $40.3 \pm 8.6$ & 3.4 & 37 & 44 & 0.70 \\
\hline $\mathrm{VO}_{2}(\mathrm{ml} / \mathrm{min})$ & $31.3 \pm 7.6$ & 5.7 & 25.7 & 37.0 & $28.7 \pm 6.2$ & 2.5 & 26 & 31 & 0.30 \\
\hline $\mathrm{VO}_{2}\left(\% \mathrm{VO}_{2} \max \right)$ & $46.4 \pm 8.6$ & 6.3 & 40.1 & 52.7 & $43.6 \pm 7.6$ & 3.0 & 41 & 47 & 0.25 \\
\hline $\mathrm{VO}_{2}\left(\% \mathrm{VO}_{2}\right.$ réserve $)$ & $41.8 \pm 9.4$ & 6.9 & 34.9 & 48.4 & $38.9 \pm 8.6$ & 3.4 & 35 & 42 & 0.29 \\
\hline FC (bpm) & $129 \pm 13$ & 10 & 120 & 139 & $119 \pm 34$ & 14 & 105 & 133 & $<0.01$ \\
\hline FC (\% FC max) & $65.0 \pm 6.5$ & 4.8 & 60.2 & 69.9 & $60.6 \pm 6.8$ & 2.7 & 5.8 & 63 & 0.03 \\
\hline FC (\%FC holds) & $60.4 \pm 18.9$ & 14.0 & 46.3 & 74.4 & $51.4 \pm 19.1$ & 7.6 & 44 & 59 & 0.17 \\
\hline RPE & $8.8 \pm 1.1$ & 1.1 & 7.7 & 10.0 & $9.2 \pm 2.7$ & 1.1 & 8 & 10 & 0.38 \\
\hline
\end{tabular}

Abbreviations: $\mathrm{p}$, level of significance; LDC, aerobic maximum power; Lipox ${ }_{\max }$ threshold of maximum oxidation of the lipids; $\mathrm{VO}_{2}$ oxygen uptake; $\mathrm{VO}_{2}$ max, maximum consumption of oxygen; $\mathrm{VO}_{2}$ oxygen uptake $\mathrm{VO}_{2}$ réserve consumption holds of oxygen; $\mathrm{FC}$ max, maximum heart rate; $\mathrm{RPE}$, perception of the effort.

\section{Discussion}

This study shows that Lipox $x_{\max }$ is not significantly influenced by the category of weight $\left(<66 \mathrm{~kg} v s>90 \mathrm{~kg}\right.$ ) of the involved judoists, except when Lipox $_{\max }$ is expressed in the form of a FC (bpm) or a percentage of FC max. Consequently, independently of the category of weight, the target intensities corresponding to Lipox $_{\max }$ in involved judoists are: $37 \%-44 \% \mathrm{LDC}, 41 \%-47 \% \mathrm{VO}_{2} \max , 35 \%$ $42 \% \mathrm{VO}_{2}$ reserve, $44 \%-59 \% \mathrm{FC}$ hold and RPE, 8 - 10. However, a distinction must be made when one expresses Lipox ${ }_{\max }$ in the form of FC absolute (107 - 110 and $120-139 \mathrm{bpm}$ for judoists of less than $66 \mathrm{~kg}$ and judoists of more than 90 $\mathrm{kg}$, respectively) or of a percentage of FC $\max (56 \%-61 \%$ and $60 \%-70 \% \mathrm{FC}$ max for the judoists of less than $66 \mathrm{~kg}$ and those of more than $90 \mathrm{~kg}$, respectively). In theory, zones of intensities target common could be used (E G, for the land period) to prescribe an intensity of exercise allowing to oxidize maximum of lipids, and thus to decrease the superfluous fatty mass of judoists of more than $90 \mathrm{~kg}$ [14] [15] and to turn over more quickly to "the weight of form" (particularly after the interseason), without with the precondition duty carrying out an effort test of calorimetry. However, individual analysis of our results reveals that only $29 \%$ of judoists of group 1 have Lipox $\max _{\max }$ in the target zones of intensities suggested against $24 \%$ in group 2 , with regard to the $\% \mathrm{VO}_{2}$ max. These results are in agreement with literature [2]. Indeed, these authors had already noticed that the significant dispersion of the values of $\operatorname{Lipox}_{\max }$ (from $43 \%$ to $59 \% \mathrm{VO}_{2}$ max) was comparable with those found in the literature among the boxers and fighters (from $33 \%$ to $75 \% \mathrm{VO}_{2}$ max). The significant inter individual variance of Lipox $_{\max }$ makes that the target zones of intensities suggested in the present study do not seem to be used on the ground for the regulation of exercises in Lipox $x_{\max }$ 
in judoists of more than $90 \mathrm{~kg}$. So in agreement with Brown and al. (2009) [7], it seems difficult to predict Lipox ${ }_{\max }$ without realizing with the precondition of effort test of calorimetry, even when one takes account of the sex and the sporting speciality. A future work could be to identify the factors which influence Lipox-

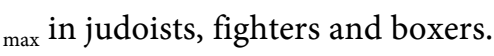

In addition, it is wise to recall that the length of the stages of the effort tests of calorimetry remains discussed [7] [16]. Indeed, some authors showed that one 6 minutes duration (by stage) is preferable at one three minutes duration if one does not want to underestimate Lipox $_{\max }$ [17]. However, this undervaluation seems to be proven at the sedentary subjects [17], but "non-existent" statistically among involved fighters [13]. Indeed, Achtenandal., 2002, showed that one duration of three minute old stages would not significantly involve a difference on Lipox $_{\max }$ of seven fighters involved $\left(\mathrm{VO}_{2} \max =64.2 \pm 1.6 \mathrm{ml} / \mathrm{kg} / \mathrm{min}\right)$ in comparison at one duration of five minute old stages (Lipox $_{\max }=5.02 \pm 0.10 \mathrm{l} / \mathrm{min}$ ) versus $4.92 \pm 0.13 \mathrm{l} / \mathrm{min}$, respectively) [13]. Similarly, we did not find a difference between the gaseous exchange $\left(\mathrm{VO}_{2}\right.$ and $\mathrm{VCO}_{2}$ during the last minute of each stage. Consequently, although should be used stages prolonged (one six minutes duration) for judoists of less than $66 \mathrm{~kg}$, the one four minutes duration old stages proposed in the present study seem sufficient since all judoists were high level and the four minutes duration borders that of a fight of judo.

In our study, $\operatorname{Lipox}_{\max }\left(44 \% \pm 8 \% \mathrm{VO}_{2} \max \right)$ was comparable with that of other authors [18] [19] [20]. Indeed, Venablesandal. (2005) found already mean Lipox $_{\max }$ to $48 \% \pm 1 \% \mathrm{VO}_{2} \max$ among 300 fighters [20]. More recently, Chenevièreandal. (2014) noted that Lipox $_{\max }$ was located at the neighbourhoods of $44 \%$ $\pm 10 \% \mathrm{VO}_{2}$ max in 32 French judoists (17 women and $15 \mathrm{men}$ ) [18]. In the same way, Stisenandal. (2006) reported mean Lipox ${ }_{\max }$ to $56 \% \pm 3 \% \mathrm{VO}_{2}$ maxamong eight sporting women involved in endurance brought back [1]. This result is higher than that of this study; however, Jeukendrup and Wallis (2005) made state that the women had their Lipox ${ }_{\max }$ with a percentage of $\mathrm{VO}_{2}$ max higher of $10 \%$ than that of the men [21]. Consequently, this difference can be explained by the effect related to the sex (men versus women).

\section{Conclusion}

This study shows that the level of category of weight in the Congolese judoists does not influence Lipox ${ }_{\max }$ (except when this last is expressed in \% FCmax). However, we note a broad interindividual variance of Lipox $_{\max }$ since only one quarter of the studied judoists have their Lipox ${ }_{\max }$ in the target zones of intensities suggested. Moreover, when one expresses as a percentage Lipox $_{\max }$, FC max and category of weight must be taken into account (56\% - 61\% FC max for less than $66 \mathrm{~kg}$ and $60 \%-70 \% \mathrm{FC}$ max for the most $90 \mathrm{~kg}$ ). Consequently, intensities target common cannot be used for the regulations of exercises in Lipox $\max _{\max }$ in the Congolese judoists involved in this study. Therefore, endurance training in judo leads to a better coordination between lipid mobilization and oxidation, which could contribute to reducing the metabolic consequences of high weight. 


\section{Acknowledgements}

The authors state not to have conflicts of interest in relation to this article.

\section{Footnote}

MJGA conceived the original idea of the article. MA worked out the procedure of experimentation, analyzed and treated the data obtained statistically, wrote the handwritten version of the article. IOJ and MKFN worked out the procedure experimentation. PTB read again the final version of the article, inliaisonwith MJGA and MA.

\section{References}

[1] Stisen, A.B., Stougaard, O., Langfort, J., Helge, J.W., Sahlin, K. and Madsen, K. (2006) Maximal Fat Oxidation Rates in Trained and Untrained Women. European Journal of Applied Physiology, 98, 497-506. https://doi.org/10.1007/s00421-006-0290-x

[2] Gonzalez-Haro, C., Galilea, P.A., Gonzalez-de-Suso, J.M., Drobnic, F. and Escanero, J.F. (2007) Maximal Lipidic Power in High Competitive Level Wrestlers and Boxers. British Journal of Sports Medicine, 41, 23-28. https://doi.org/10.1136/bjsm.2006.029603

[3] Achten, J. and Jeukendrup, A.E. (2003) Maximal Fat Oxidation during Exercise in Trained Men. International Journal of Sports Medicine, 24, 603-608. https://doi.org/10.1055/s-2003-43265

[4] Achten, J., Venables, M.C. and Jeukendrup, A.E. (2003) Fat Oxidation Rates Higher during Running Compared with Cycling over a Wide Range of Intensities. Metabolism, 52, 747-752. https://doi.org/10.1016/S0026-0495(03)00068-4

[5] Brown, J.F., Boegner, C., Raynaud, E. and Mercier, J. (2009) Contrairement à une idée reçue, les femmes n'oxydent pas plus de lipides à l'effort que les hommes, mais leur Lipox ${ }_{\max }$ survient à une puissance plus élevée. Science \& Sports, 24, 45-58. https://doi.org/10.1016/j.scispo.2007.11.006

[6] Franchini, E., Del Vecchio, F.B., Matsushigue, K.A., et al. (2011) Physiological Profiles of Elite Judo Athletes. Sports Medicine, 41, 147-166.

https://doi.org/10.2165/11538580-000000000-00000

[7] Brown, J.F., Halbeher, C., Fédou, C. and Mercier, J. (2007) Le Lipox ${ }_{\max }$ (niveau d'oxydation maximal des lipides à l'exercice) peut-il être déterminé sans effectuer de calorimétrie d'effort? Diabetes \& Metabolism, 35, A86. https://doi.org/10.1016/S1262-3636(09)72047-6

[8] Sacripanti, A. (2003) Biomeccanica del judo. Edizioni Mediterranee, Roma, 205 p.

[9] Achten, J., Gleeson, M. and Jeukendrup, A.E (2002) Determination of the Exercise Intensity That Elicites Maximal Fat Oxidation. Medicine \& Science in Sports \& EXercise, 34, 92-97.

[10] Del Vecchio, F.B., Hirata, S.M. and Franchini, E. (2011) A Review of Time-Motion Analysis and Combat Development in Mixed Martial Arts Matches at Regional Level Tournaments. Percept Mot Skills, 112, 639-648. https://doi.org/10.2466/05.25.PMS.112.2.639-648

[11] Borg, G. (1970) Perceived Exertion as an Indicator of Somatic Stress. Scandinavian Journal of Rehabilitation Medicine, 2, 92-98.

[12] Durnin, J.V. and Wormersley, J. (1974) Body Fat Assessed from Total Body Density 
and Its Estimation from Skinfold Thickness: Measurements on 481 Men and Women Aged from 16 to 72 Years. British Journal of Nutrition, 32, 77-97. https://doi.org/10.1079/BJN19740060

[13] Achten, J., Gleeson, M. and Jeukendrup, A.E. (2002) Determination of the Exercise Intensity That Elicits Maximal Fat Oxidation. Medicine \& Science in Sports \& Exercise, 34, 92-97. https://doi.org/10.1097/00005768-200201000-00015

[14] Garrigue, E., Glisezinski, I., Harant, I., Moro, C., Pillard, F., Crampes, F. and Rivière, D. (2006) Métabolisme Lipidique et Exercice Musculaire chez le Sujet Obèse. Science \& Sports, 68, 68-73. https://doi.org/10.1016/j.scispo.2005.06.011

[15] Le Gallais, D. and Millet, G. (2007) La Préparation Physique: Optimisation et Limites de la Performance Sportive. In: Le Gallais, D. and Millet, G., Eds., Evaluation de la Performance Physique en Laboratoire, Massonp, Paris, 247-248.

[16] Edward, F. and Coyle, E. (1995) Métabolisme des Graisses Pendant l'Exercice: Nouveaux Concepts. Sports Science Exchange, 59, 1-8.

[17] Bordenave, S., Flavier, S., Fédou, C., Brun, J.F. and Mercier, J. (2002) Exercise Calorimetry in Sedentary Subjects: Procedure Based on Short 3 Min Steps Underestimate Carbohydrate Oxidation and Overestimate Lipid Oxidation. Diabetes, Obesity and Metabolism, 33, 379-384.

https://doi.org/10.1016/j.diabet.2007.04.003

[18] Chenevière, X., Malatesta, D., Peters, E.M. and Borrani, F. (2014) A Mathematical Model to Describe Fat Oxidation Kinetics during Graded Exercise. Medicine \& Science in Sports \& Exercise, 46, 1615-1625.

[19] Coquart, J.B.J., Grosbois, J.M., Nycz, M., Bart, F. and Garcin, M. (2015) Influence du Niveau de Performance sur le Seuil d'Oxydation Maximale des Lipides $\left(\right.$ Lipox $\left._{\max }\right)$ chez des Sportifs et Sportives Français. Science \& Sports, 30, 32-37.

[20] Venables, M.C., Achten, J. and Jeukendrup, A.E. (2005) Determinants of Fat Oxidation during Exercise in Healthy Men and Women: A Cross-Sectional Study. Journal of Applied Physiology, 98, 160-167. https://doi.org/10.1152/japplphysiol.00662.2003

[21] Jeukendrup, A.E. and Wallis, G.A. (2005) Measurement of Substrate Oxidation during Exercise by Means of Gas Exchange Measurements. International Journal of Sports Medicine, 26, S28-S37. https://doi.org/10.1055/s-2004-830512

\section{Scientific Research Publishing}

Submit or recommend next manuscript to SCIRP and we will provide best service for you:

Accepting pre-submission inquiries through Email, Facebook, LinkedIn, Twitter, etc. A wide selection of journals (inclusive of 9 subjects, more than 200 journals)

Providing 24-hour high-quality service

User-friendly online submission system

Fair and swift peer-review system

Efficient typesetting and proofreading procedure

Display of the result of downloads and visits, as well as the number of cited articles

Maximum dissemination of your research work

Submit your manuscript at: http://papersubmission.scirp.org/

Or contact jbm@scirp.org 